\title{
Correlation of Biomarker and Biophysical Parameters with Microflora at Different Skin Sites in Young Women (20-21yrs.) of Meerut
}

\author{
Sonia Sharma ${ }^{1 *}$, Alka Sagar ${ }^{1}$, Saurabh Singh Yadav², Pramod W. Ramteke ${ }^{3}$ \\ ${ }^{1}$ Meerut Institute of Engineering and Technology, Meerut, India \\ ${ }^{2}$ Swami Vivekanand Subharti University, Meerut, India \\ ${ }^{3}$ Sam Higginbottom University of Agriculture Technology and Sciences, Allahabad, India \\ *Corresponding author
}

\section{Keywords \\ Biochemical characterization, Biomarkers, \\ Biophysical parameters, Dermal health, Microflora, Skin}

\section{Article Info}

Accepted: 08 January 2020 Available Online: 10 February 2020

\section{A B S T R A C T}

Dermal health is the outcome of dynamic interactions between the microflora and immune networks to influence the health and overall wellbeing. Biophysical parameters reflect the functional integrity of skin. Biomarkers LL-37 and HBD 2, 3 have broad spectrum amino acid activity that plays role in epithelial defense system. The aim of the present work was to find out exiting correlation between the isolated genera, biophysical parameters and biomarkers of skin. Methods of isolated genera from seven cutaneous site from 45 young girls (21-22 yrs.) were ccorrelated with Biophysical parameters such as trans-epidermal water loss, epidermal hydration, skin $\mathrm{pH}$, dermal health, level of biomarkers LL-37 and HBD, Meerut Institute of Engineering and Technology (MIET), Meerut. One hundred six (136) isolates presumptively identified as Staphylococcus epidermidis, Pseudomonas sp., Lactobacillus sp. Propionobacterium sp. on the basis of selective media and biochemical characterization were analyzed. Total viable count was moderately correlated with LL-37, HBD-2,3, epidermal hydration and skin gloss, bears weak positive correlation with TEWL and skin lesions and weak negative correlation with $\mathrm{pH}$, redness, scales and skin integrity. The study findings suggested that areas having better dermal health are positively correlated with microbial load and biomarker LL-37 and HBD 2,3. Dermal health is a consequence of normal flora and antimicrobial peptides can be used in human skin ointments for treatment of skin disorders.

\section{Introduction}

Skin is the semipermeable filtration system having many dynamic interactions with microbes that reside on skin surface. Many experiments had revealed the mutual beneficial relationship of these bacteria with the host (Cogen et al., 2008).
The most direct benefit is the production of lysozyme, acidity ( $\mathrm{pH}$ 4.5-5.9) which impart antifungal and antimicrobial properties, and defensins (HBD-2,HBD-3), antimicrobial peptide marker LL-37, HBD-2,HBD3, lantibiotics, and other molecules that act to resist co-colonization by pathogens (Cogen $e t$ al., 2010; Nakatsuji et al., 2013; Lai et al., 
2009,2010,2013; Naik et al., 2012) stimulate host immune system by enhancing antibody production, stimulate phagocytosis and clearance mechanisms, and augment interferon and cytokine production (Moon, 2012; Nipa, 2015).

In contrast, some of the bacteria present on skin surface such as Staphylococcus aureus when applied to the surface of mouse skin can initiate harmful events that exacerbate the allergic responses Nakamura et al., 2013.

LL-37 derives its name due to two leucine leading residues with overall length of 37 amino acids. HBD are the human beta defensins which are cysteine rich and have broad spectrum amino acid activity play role in epithelial defense system (Zheng et al., 2016, Hans et al., 2014; Crack et al., 2012).

Certain factors such as the amount of perspiration, anatomic location, the amount of sebum and sweat production, age and hormonal level of the host determines the type and density of bacteria (Chiller et al., 2001).

Previously individual role of LL-37, HBD and microbes had been studied in cutaneous defense in some diseases (Zheng et al., 2016; Hans et al., 2014; Crack et al., 2012).

It is hypothesized that there exist some relation between the concentration of these antimicrobial peptides with the density and type of microbes present at different anatomical sites on skin.

For this purpose the present work was planned to find out the correlation between microbial load, biophysical parameters such as Trans epidermal water loss, epidermal hydration, skin $\mathrm{pH}$, dermal health, level of biomarkers LL-37 and HBD2,3 using healthy young females.

\section{Materials and Methods}

\section{Study design}

This study was carried out for one month from January to February 2019 in the department of Biotechnology \& Microbiology at Meerut Institute of Engineering \& Technology affiliated to CCS University (U.P.), Meerut, India. The sample size was calculated using website.

http://www.raosoft.com/samplesize.html. 45 (Forty Five) healthy woman (21-22yrs) were included in this experimental study so that correlation can be found out between healthy skin and biophysical parameters. Participants had not received antibiotics 15 days before the sampling avoid any other medicine during the test period and provided informed consent to participate in the study.

The average high and low temperature during study was $10-17^{0} \mathrm{C}$ with maximum of $24{ }^{0} \mathrm{C}$ and $56 \%$ R.H. The body sites chosen for study were washed 12 hrs before the study. The participants were allowed to bathe only with water and restrict the use of any shampoo soap and beauty product during study period.

\section{Isolation of bacteria}

In this study, different areas: (alar crease) corner of nose, hand back, (reticuloauricular crease) backside of ear, volar forearm, toe webs, interdigital space, antecubital fossa from each individual were sampled after swabbing the site in three replicates (thrice a week) (Grice et al., 2008) and inoculated on different media like mannitol salt agar aerobically incubated, lactobacillus selection agar, thioglychollate broth, blood agar (anaerobic jar). After incubation at $37-40^{\circ} \mathrm{C}$ for 24-48hrs, bacterial colonies were isolated. 
Bacterial cultures were maintained on slants at $-20{ }^{0}$ C. (Ian et al., 2016; Julie et al.,2019).

\section{Biochemical identification of isolated bacteria}

The identification of bacteria was based on morphological characteristics and biochemical tests carried out on the isolates.

Morphological characteristics observed for each bacteria colony after $24 \mathrm{~h}$ of growth included colony appearance; shape, elevation, edge, optical characteristics, consistency, colony surface and pigmentation.

Biochemical characterizations using Gram staining techniques, Catalase, Methyl red, Voges-proskaeur, Indole, Sugar fermentation, Starch hydrolysis, Citrate, Urease, Gelatin hydrolysis for tentative identification of bacteria (Olutiola et al., 2000).

\section{Study of biomarkers}

Collection of stratum corneum was standardized, using the same tape, pressed against the skin for 10 seconds stored at $20{ }^{\circ} \mathrm{C}$.

Samples were aliquoted into Eppendorf tubes and stored at $-80{ }^{\circ} \mathrm{C}$. Tape-strippings were analysed for the presence of biomarkers of AMPs (LL-37, $\beta$ - defensins (HBD-2, HBD3)).

For quantification, LL-37 and $\beta$ - defensins were extracted from last $4 / 5$ tapes using 15 $\mathrm{mL}$ Tris bufered saline and the extract was kept at $4^{\circ} \mathrm{C}$ overnight. Each extract was filtered through polytetrafluoroethene (PTFE) membrane and the trapped corneocytes in the membrane filter were analysed using chemiluminescence immuno-detection method (Maja-Lisa Clausen et al., 2018)

\section{Biophysical parameters}

The measurement of biophysical parameters of the skin was performed using 4 different instruments: Skin pH-Meter® (PH905), SkinGlossymeter® GL 200, Tewameter TM 210®, Corneometer CM 820. The skin of study participants was cleaned with mild soap $2 \mathrm{hrs}$ before taking the measurement. (Harvey et al., 2017).

\section{Statistical analysis}

All experiments were carried out in triplicates. Data obtained were analyzed by $\mathrm{T}$ test and one-way analysis of variance (ANOVA). Means were compared by Duncan's New Multiple Range test (SPSS Statistics for Windows, version 10.0) (SPSS Inc., Chicago, Ill., USA). Differences were considered significant at $\mathrm{p}<0.05$.

\section{Results and Discussion}

The body sites were chosen in this study on the basis of the varied bacterial compositions of different skin areas. Superficial swabs were employed because this method was less invasive and was reported to yield similar microbial profile to that associated with skin scraping of epidermis or punch biopsy of full thickness of epidermis and dermis (Grice et al.,. 2008). Samples were spread-plated onto the surface of BA (Blood Agar) and MSA (Mannitol Salt Agar), LSA (Lactobacillus Selective Agar), CLED (Cystine Lactose Electrolyte-Deficient Agar) plates and the plates that contained visible growth were counted. The minimum TVC was at antecubital fossa with maximum count at reticulo-auricular crease shown in table no.1. S.epidermidis form white colored colonies, $S$. aureus was observed as golden coloured colonies on MSA and deep yellow colonies on CLED, white colonies observed at LSA were of Lactobacillus. 
Table.1 Total viable count of microorganisms at different skin sites (Mean \pm S.E.)

\begin{tabular}{|l|l|l|}
\hline S.No. & Samples & No of TVC \\
\hline 1 & Volar forearm & $102 \pm 25$ \\
\hline 2 & Retroauricular crease & $136 \pm 20$ \\
\hline 3 & Alar crease & $106 \pm 15$ \\
\hline 4 & Toes web space & $109 \pm 20$ \\
\hline 5 & Hand back & $104 \pm 30$ \\
\hline 6 & Inter digital space & $107 \pm 15$ \\
\hline 7 & Antecubital fossa & $94 \pm 20$ \\
\hline
\end{tabular}

Table.2 Comparative growth of microorganisms from skin samples on different media

\begin{tabular}{|c|c|c|c|c|c|c|}
\hline S.No. & Samples & \multicolumn{2}{|c|}{ Mannitol salt agar } & \multirow{2}{*}{$\begin{array}{c}\text { LBS agar } \\
8^{\text {a }}\end{array}$} & \multirow{2}{*}{$\begin{array}{c}\text { CLED agar } \\
24^{\text {ns }}\end{array}$} & \multirow{2}{*}{$\begin{array}{c}\text { Blood agar } \\
24^{\Delta \cdot}\end{array}$} \\
\hline 1 & Volar forearm & $4^{* \boldsymbol{\Lambda}}$ & $42^{\mathrm{ns}}$ & & & \\
\hline 2 & $\begin{array}{l}\text { Retroauricular } \\
\text { crease }\end{array}$ & $10^{* \Delta \operatorname{\Delta ad}}$ & $46^{\mathrm{ns}}$ & $12^{\mathrm{ns}}$ & $28^{\mathrm{ns}}$ & $36^{* \Delta \cdot 00}$ \\
\hline 3 & Alar crease & $12^{* \mathbf{A n O D}}$ & $41^{\mathrm{ns}}$ & $10^{\mathrm{ns}}$ & $29^{\text {ns }}$ & $14^{\circ 4}$ \\
\hline 4 & Toes web space & $1^{\Delta *}$ & $39^{\mathrm{ns}}$ & $20^{\wedge \cdot 0}$ & $34^{\mathrm{ns}}$ & $15^{\wedge \bullet}$ \\
\hline 5 & Hand back & $1^{\Delta \bullet}$ & $37^{\text {ns }}$ & $16^{\bullet}$ & $30^{\mathrm{ns}}$ & 20 \\
\hline 6 & Inter digital space & $1^{\Delta \star \Delta}$ & $40^{\mathrm{ns}}$ & $16^{\mathrm{ns}}$ & $32^{\mathrm{ns}}$ & $18^{*}$ \\
\hline 7 & Antecubital fossa & $1^{\Delta \wedge}$ & $38^{\text {ns }}$ & $6^{10}$ & $28^{\mathrm{ns}}$ & 20 \\
\hline \multicolumn{2}{|c|}{ Tentative identification } & S.aureus & S.epidermidis & Lactobacillus & Pseudomonas & $\begin{array}{l}\text { Propioni } \\
\text { bacterium }\end{array}$ \\
\hline
\end{tabular}

* $\mathrm{P}<0.05$ compared to Interdigital space, $-\mathrm{P}<0.05$ compared to toe web space, $\mathrm{P}<0.05$ compared to reticuloauricular crease, $\mathbf{\Lambda} \mathrm{P}<0.05$ compared to alar crease, $\bullet \mathrm{P}<0.05$ compared to volar forearm, $\mathbf{0} \mathrm{P}<0.05$ compared to hand back, $>\mathrm{P}<0.05$ compared to antecubital fossa.

Green colonies with typical matted surface and rough periphery on CLED were of Pseudomonas. Propionibacterium were observed as pinprick-sized white glossy opaque neat-edged colonies on the blood agar. The details of colonial growth on different media are shown in table no. 2 .

The fig. 1 shows the effect of abiotic stress on the growth of bacteria isolated from different sites. The microflora from reticuloauricular crease and alar crease are able to tolerate the stress whereas the flora from volar forearm is somewhat sensitive to stress compared with other sites.The biochemical characterization (fig.2) in addition to growth on specific media (table no. 2) leading to their tentative identification revealed that S.epidermidis is the predominant organism at all the sites taken into account in the study and $S$. aureus is the least found organism.

Pseudomonas is the second highest organism in toe web and interdigital space with Propionibacterium occupying the third place in its abundance followed by Lactobacillus in the study. 


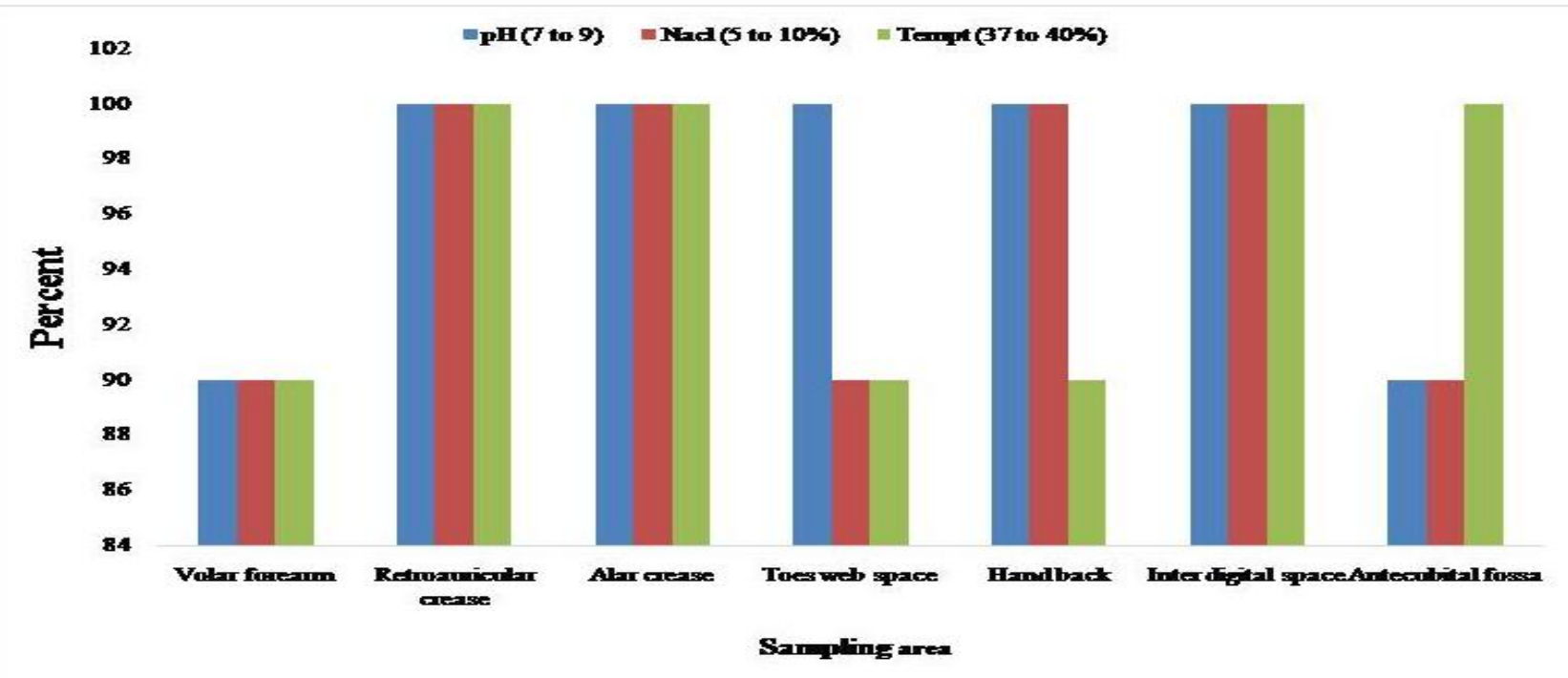

Fig.1 Characterization of isolated bacteria for Abiotic stress

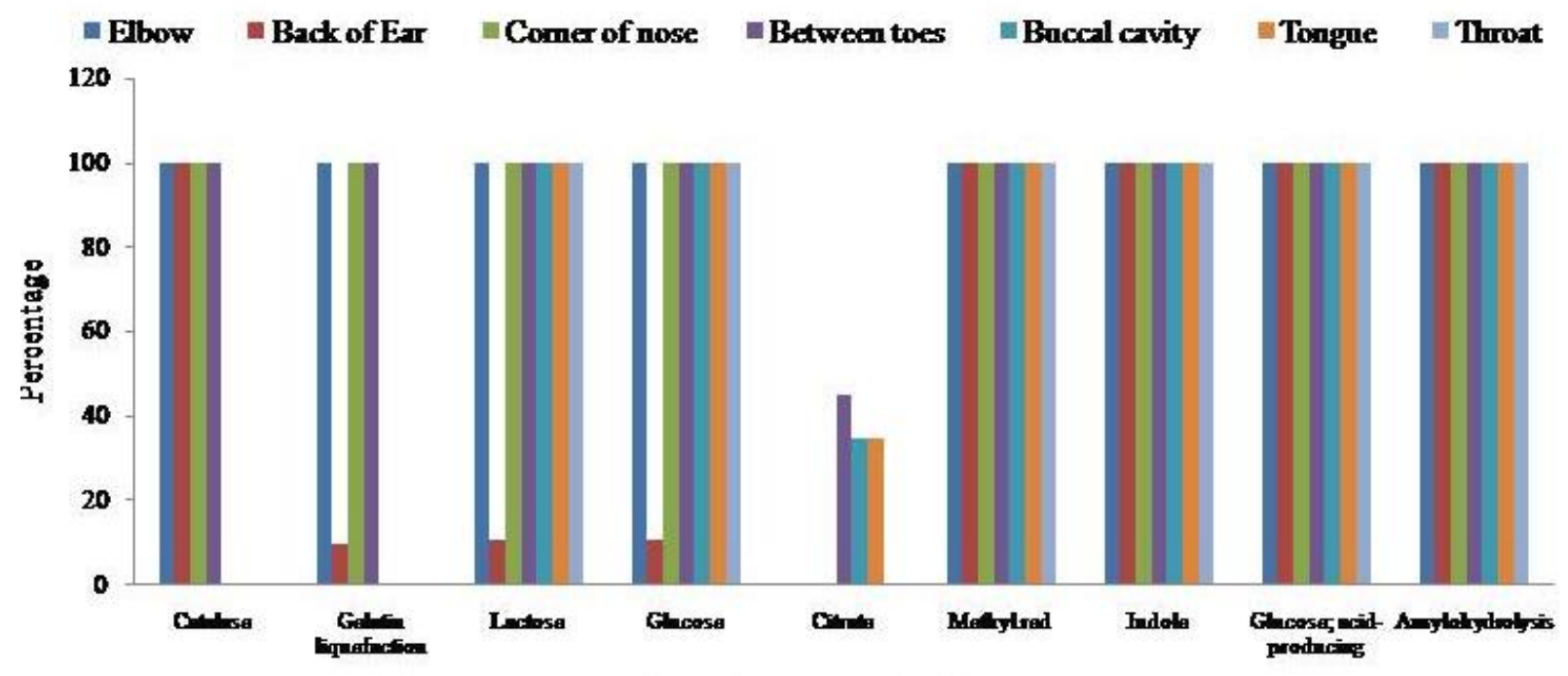

Biochemicalcharacteristics

Fig.2 Biochemical characteristics of isolated bacteria

The highest concentration of biomarker are present at alar crease which has shown in table.3. Lowest concentration of defensins HBD-3 and canthalidins LL-37 at interdigital space and HBD-2 at toe web space.

The evaluation of biophysical parameters as revealed from table no. 4 the epidermal hydration was highest at reticuloauricular crease and lowest at interdigital space.

The transepidermal water loss was lowest at antecubital fossa and highest at toe web space. The skin gloss was highest at reticuloauricular crease and lowest at antecubital fossa. 
Table.3 Level of different biomarkers (antimiocrobial peptides) at different skin sites.

\begin{tabular}{|c|c|c|c|c|}
\hline \multirow[t]{2}{*}{ S.no. } & \multirow[t]{2}{*}{ Samples } & \multicolumn{3}{|l|}{ Biomarkers } \\
\hline & & HBD-2(pg/ml) & HBD-3(pg/ml) & LL-37 (pg/ml) \\
\hline 1 & Volar forearm & $0.41 \pm 0.02^{\text {D }}$ & $0.07 \pm 0.008^{\text {व }}$ & $0.18 \pm 0.04^{\mathrm{ns}}$ \\
\hline 2 & Retroauricular crease & $0.43 \pm 0.02^{\square}$ & $0.50 \pm 0.03^{* \square}$ & $0.91 \pm 0.04^{* \square}$ \\
\hline 3 & Alar crease & $0.39 \pm 0.04^{* a}$ & $0.54 \pm 0.06^{* \mathrm{D}}$ & $0.98 \pm 0.09^{*}$ व \\
\hline 4 & Toes web space & $0.12 \pm 0.09^{2}$ & $0.10 \pm 0.04^{2}$ & $0.16 \pm 0.01^{2 x}$ \\
\hline 5 & Hand back & $0.21 \pm 0.04$ & $0.12 \pm 0.03^{2}$ & $0.20 \pm 0.03$ \\
\hline 6 & Inter digital space & $0.11 \pm 0.08$ & $0.07 \pm 0.01$ & $0.12 \pm 0.04^{2}$ \\
\hline 7 & Antecubital fossa & $0.18 \pm 0.09$ & $0.10 \pm 0.06$ & $0.21 \pm 0.088$ \\
\hline
\end{tabular}

Table.4 Biophysical parameters of various skin sites

\begin{tabular}{|c|c|c|c|c|c|c|c|}
\hline \multirow{2}{*}{$\begin{array}{l}\text { Biophysical } \\
\text { Parameter }\end{array}$} & \multicolumn{7}{|c|}{ Sampling area } \\
\hline & $\begin{array}{l}\text { Volar } \\
\text { forearm }\end{array}$ & $\begin{array}{l}\text { Retroaur } \\
\text { icular } \\
\text { crease }\end{array}$ & $\begin{array}{l}\text { Alar } \\
\text { crease }\end{array}$ & $\begin{array}{l}\text { Toes web } \\
\text { space }\end{array}$ & $\begin{array}{l}\text { Hand } \\
\text { back }\end{array}$ & $\begin{array}{l}\text { Inter } \\
\text { digital } \\
\text { space }\end{array}$ & $\begin{array}{l}\text { Antecubi } \\
\text { tal fossa }\end{array}$ \\
\hline $\begin{array}{l}\text { Epidermal } \\
\text { Hydration }\end{array}$ & $\begin{array}{l}42.12 \\
\pm 1.21\end{array}$ & $\begin{array}{l}72.12 \pm 4 \\
21^{\bullet *} \cdot \mathbf{\Delta}\end{array}$ & $\begin{array}{l}59.12 \\
\pm 2.94\end{array}$ & $\begin{array}{l}17.24 \pm 1 \\
54^{0 A 0} * \text { 口 }\end{array}$ & $\begin{array}{l}51.42 \pm 4 \\
32 * *\end{array}$ & $\begin{array}{l}14.24 \pm 2.2 \\
1 * * \mathbf{\Delta}=5\end{array}$ & $\begin{array}{l}54.12 \pm 2 \\
84 *\end{array}$ \\
\hline $\begin{array}{l}\text { TEWL } \\
(\mathrm{g} / \mathrm{m} 2 \mathrm{~h})\end{array}$ & $\begin{array}{l}5.12 \\
\pm 1.20^{\text {\#* }}\end{array}$ & $\begin{array}{l}9.24 \\
\pm 2.34\end{array}$ & $\begin{array}{l}10.86 \\
\pm 0.85\end{array}$ & $\begin{array}{l}38.51 \pm 2 . \\
12\end{array}$ & $\begin{array}{l}9.28 \pm 1.2 \\
4 * *\end{array}$ & $\begin{array}{l}38.51 \pm 5.6 \\
4\end{array}$ & $\begin{array}{l}2.88 \pm 0.8 \\
4^{* * \Delta}\end{array}$ \\
\hline $\begin{array}{l}\text { Gloss, } \\
\text { Glossimeter } \\
\text { units }\end{array}$ & $\begin{array}{l}9.14 \\
\pm 0.86^{\mathrm{ns}}\end{array}$ & $\begin{array}{l}9.48 \\
\pm 0.28^{\mathrm{ns}}\end{array}$ & $\underset{\mathrm{ns}}{7.16 \pm 1.23}$ & $\begin{array}{l}5.14 \pm \\
0.64^{\text {ns }}\end{array}$ & $\begin{array}{l}6.12 \pm 0.8 \\
9^{\mathrm{ns}}\end{array}$ & $\begin{array}{l}5.14 \pm 0.89 \\
\mathrm{~ns}\end{array}$ & $\begin{array}{l}4.91 \pm 0.9 \\
4^{\mathrm{ns}}\end{array}$ \\
\hline $\mathrm{pH}$ & $5.5 \pm 0.34^{\mathrm{ns}}$ & $\begin{array}{l}5.2 \\
\pm 0.71\end{array}$ & $\underset{\mathrm{ns}}{5.4 \pm} 0.21$ & $\begin{array}{l}6.1 \pm \\
0.25^{\text {a }}\end{array}$ & $\begin{array}{l}5.0 \pm \\
0.6\end{array}$ & $5.2 \pm 0.6^{\mathrm{ns}}$ & $5.8 \pm 0.43^{\text {口 }}$ \\
\hline
\end{tabular}

$* \mathrm{P}<0.05$ compared to Interdigital space, $\square \mathrm{P}<0.05$ compared to toe web space, $\uparrow \mathrm{P}<0.05$ compared to reticuloauricular crease, $\boldsymbol{\Delta} \mathrm{P}<0.05$ compared to alar crease, $\bullet \mathrm{P}<0.05$ compared to volar forearm, a $\mathrm{P}<0.05$ compared to hand back, $\quad \mathrm{P}<0.05$ compared to antecubital fossa. 
Table.5 Grading of skin sampled for various dermal parameters

\begin{tabular}{|c|c|c|c|c|c|c|}
\hline S.no. & Samples & Dryness & Redness & Scales & Skin integrity & Skin lesions \\
\hline 1 & $\begin{array}{l}\text { Volar } \\
\text { forearm }\end{array}$ & $2.34 \pm 0.12$ & $\underset{n=}{0.54 \pm 0.08}$ & $1.84 \pm 0.21^{* *}$ & $1.62 \pm 0.31^{20}$ & $0.86 \pm 0.12^{\square}$ \\
\hline 2 & $\begin{array}{l}\text { Retroauricul } \\
\text { ar crease }\end{array}$ & $0.27 \pm 0.07^{\bullet * \Delta \text { 口 }}$ & $\underset{\mathrm{ns}}{0.54 \pm 0.12}$ & $0.34 \pm 0.05^{\bullet * \Delta \text { व }}$ & $0.64 \pm 0.09^{\bullet * \Delta \square \square}$ & $0.71 \pm 0.21^{\text {D }}$ \\
\hline 3 & Alar crease & $1.48 \pm 0.32$ & $\begin{array}{l}0.49 \pm 0.14 \\
\text { ns }\end{array}$ & $1.28 \pm 0.24^{*}$ & $1.42 \pm 0.13^{-x}$ & $0.78 \pm 0.03^{\circ}$ \\
\hline 4 & $\begin{array}{l}\text { Toes web } \\
\text { space }\end{array}$ & $1.76 \pm 0.14$ & $\underset{\mathrm{ns}}{0.54 \pm 0.15}$ & $1.62 \pm 0.32^{ \pm 0}$ & $1.85 \pm 0.43^{.5}$ & $0.52 \pm 0.08^{\square}$ \\
\hline 5 & Hand back & $1.25 \pm 0.13$ & $\underset{\mathrm{ns}}{0.64 \pm 0.13}$ & $0.52 \pm 0.09^{\bullet * \Delta \text { व }}$ & $1.25 \pm 0.11$ & $1.32 \pm 0.09^{\bullet *}$ \\
\hline 6 & $\begin{array}{l}\text { Inter digital } \\
\text { space }\end{array}$ & $1.84 \pm 0.23^{a x}$ & $\begin{array}{l}0.46 \pm 0.09 \\
\text { ns }\end{array}$ & $1.78 \pm 0.08^{ \pm 0}$ & $1.92 \pm 0.31^{.0 x}$ & $0.43 \pm 0.28^{\mathbf{D}}$ \\
\hline 7 & $\begin{array}{l}\text { Antecubital } \\
\text { fossa }\end{array}$ & $0.34 \pm 0.09^{\bullet * \Delta \text { 口 }}$ & $\begin{array}{l}0.68 \pm 0.07 \\
\text { ns }\end{array}$ & $0.41 \pm 0.05^{\bullet * \Delta \text { ㅁ }}$ & $0.72 \pm 0.04^{\bullet * \Delta \text { 口 }}$ & $0.84 \pm 0.12^{\text {व }}$ \\
\hline
\end{tabular}

* $\mathrm{P}<0.05$ compared to Interdigital space, $\boldsymbol{- P}<0.05$ compared to toe web space, $\$ \mathrm{P}<0.05$ compared to reticuloauricular crease, $\mathbf{\Lambda} \mathrm{P}<0.05$ compared to alar crease, $\bullet \mathrm{P}<0.05$ compared to volar forearm, $\mathbf{0} \mathrm{P}<0.05$ compared to hand back, $>\mathrm{P}<0.05$ compared to antecubital fossa.

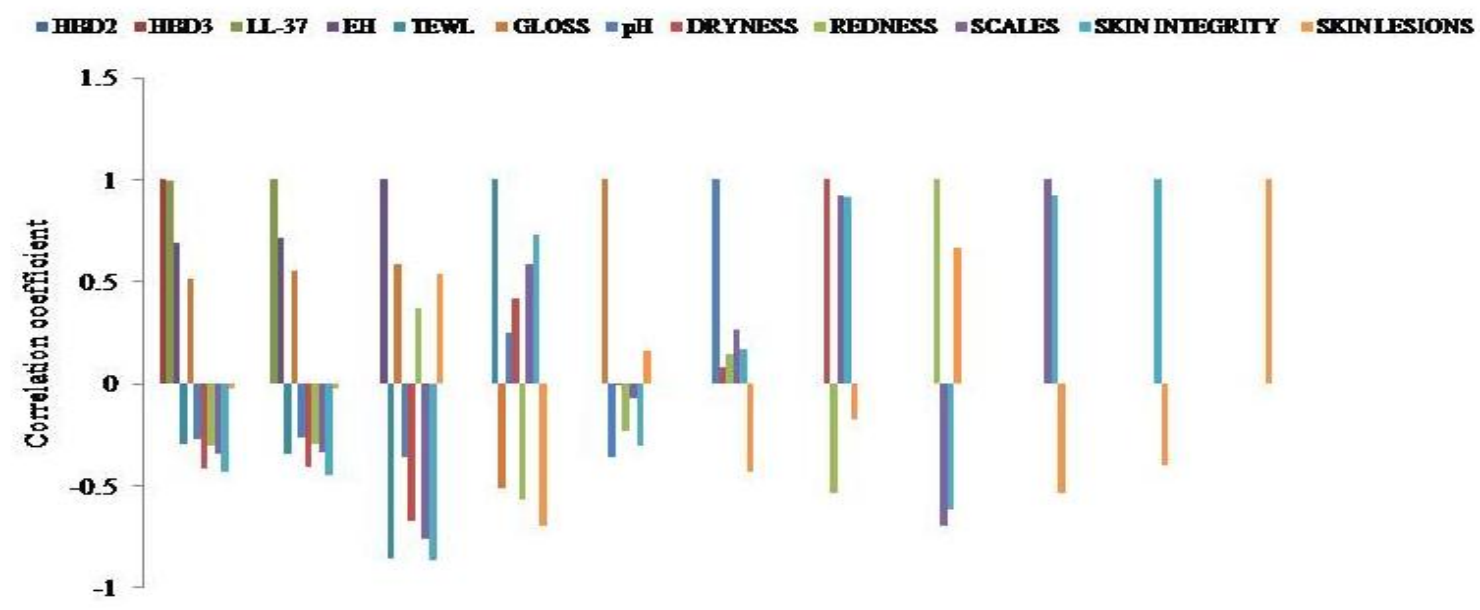

Fig.3 Correlation coefficient of microbial load with biophysical and biomarkers

The Skin tolerance test showed skin tolerance grading was lowest at reticuloauricular crease depicting better dermal health and highest at volar forearm as shown in table no. 5 .

The statistical analysis depicted that samples collected from different sites vary significantly from each other in above parameters undertaken in the present study.
The correlation analysis as shown in fig no. 3 reveals total viable count was moderately correlated with LL-37, HBD-2,3, epidermal hydration and skin gloss, bears weak positive correlation with TEWL and skin lesions and weak negative correlation with $\mathrm{pH}$, redness, scales and skin integrity. HBD-2 bears a strong positive relation with LL-37, skin gloss and epidermal hydration. HBD-3 was found 
to be strongly correlated with LL-37 and moderately correlated with skin gloss.LL-37 was positively correlated with epidermal hydration.

Epidermal hydration was found to be positively correlated with TVC and biomarkers LL-37, HBD-2,3 and skin gloss. Skin $\mathrm{pH}$ was positively correlated with skin lesions. TEWL has positive correlation with skin lesions. Dryness was positively correlated with skin lesions and negative correlation with rest all traits.

Scales were positively correlated with dryness, TEWL and skin integrity in the present study. Skin lesions had positive correlation with redness. Skin lesions had positive correlation with redness and epidermal hydration negative or weak positive correlation with all other traits.

Skin is a complex ecosystem as it harbor different microbial communities depending on the local microenvironment prevailing at specific site (Domingos et al., 2001) individual health status, eating behavior and environmental contacts, age related differences (relative dominance of lactobacilli in neonatal skin as compared to Propionibacteria in the mother) (Tacconelli et al., 2001).

The development and maturation of systemic immune system depends on exposure of young child to microbes (Teruki et al., 2018) influencing the growth and function of all organ systems, including the brain. In the present study Staphylococcus epidermidis was the most common isolate of the cutaneous microbiota.

This inference is supported by the investigation done by (Overturf et al., 1990) which explained that more than $90 \%$ of all aerobic resident microbiota is Staphylococcus epidermidis, it amplifies the keratinocyte response to pathogens by educating the skin's immune system through the production of antibacterial peptides (bacteriocins: epidermin, epilancin K7, epilancin 15X, Pep5 and staphylococcin 1580), lantibiotics: lanthionine-containing antibacterial peptides(Bierbaum G et al., 1996), immunomodulatory properties (inhibition of inflammatory cytokine production), tumor necrosis factor receptor-associated factor (TRAF 6),TRAF1(Lai et al., 2009) pheromone cross-inhibition $(\delta$-haemolysin, $\delta$ toxin or $\delta$-lysin) (Nakamura et al., 2013) and enhanced expression of tight junction protein which promote barrier function, promotes the expression of host AMPs such as cathelicidins and $\beta$-defensins causes microbial lipid membrane leakage (Nakatsuji et al., 2017), blocks NF-kB inhibition (Wanke et al., 2011) and inhibit colonisation with potential pathogens. S. aureus is found in low numbers as compared to other commensal organisms because host skin cells constantly sample the microorganisms inhabiting the epidermis and dermis via pattern recognition receptors (PRRs).

The activation of agr loci leads to a downregulation of virulence factors as signal is sent to the bacterium that an appropriate density is reached (Otto et al., 2001) and ultimately lead to colonization inhibition (Otto 2001).

The commensal species thus prevent pathogen growth and maintain the stability of the resident cutaneous community (Cogen et al., 2007).(Hoyle et al., in 1991) ) reported the presence of toll-like receptors (TLRs) TLR2 mediated by LTA (lipoteichoic acid) which specify pathogen-associated molecular patterns called bacterial priming and mast cell-mediated antiviral immunity (Wanke et al., 2011) thereby activating the innate immune receptors providing efficient and 
effective response of keratinocytes (Dekio et al., 2005). Some strains of Staphylococcus epidermidis produce 6-Nhydroxyaminopurine (6-HAP), a DNA polymerase inhibitor which selectively inhibits proliferation of tumor lines (Teruki et al., 2018) suggesting that the microbiome can act across the epidermis and interact with cells in the dermis and may confer protection against skin cancer.

AMPs are the defense molecules exhibit immunomodulatory activity by inducing proliferation differentiation and migration of cells along with regulating apoptosis of neutrophils and epithelial cells. Cathelicidin LL-37 is one of the few human bactericidal peptides with potent anti-Staphylococcal activity against $S$. epidermidis biofilms in vitro (Saporito et al., 2018) forms an effective barrier against bacteria (Nelson et al., 2009).

P.acnes and Pseudomonas bacteria possess next highest numbers in the samples collected in our study followed by Lactobacillus. Specific genes encoding for triacylglycerol lipase and lysophospholipase were identified in the Propionibacterium species, these enzymes specifically promotes triglyceride hydrolysis and propionic acid secretion resulting in an acidic $\mathrm{pH}$ which limits the growth of Pseudomonas (Megyeri, 2018), reduce Methicillin- resistant $S$. aureus (MRSA), S. pyogenes (Moon, 2012) and promote the growth of lipophilic yeasts including Malassezia species (Platsidaki, et al., 2018)

Pseudomonas produces pseudomonic acid and pyrrolnitrin which works against Staphylococcal and Streptococcal, Helicobacter pylori, Candida krusei, Candida albicans, Torulopsis glabrata, Saccharomyces cerevisiae and Aspergillus fumigatus. A dense glycocalyx biofilm is formed on CA filaments, Type IV pili, phospholipase C, phenazine compounds, including pyocyanin, phenazine-1-carboxylic acid (PCA), 1hydroxyphenazine and phenazine-1carboxamide (Xu et al., 2017) kills the fungus (Xu et al., 2014)and dermatophytes (Treat et al., 2007).

Lactobacillus part of natural moisturizing factor (NMF) exerts beneficial effect on skin by producing lactic acid, hyaluronic acid, diacetyl improves the stratum corneum barrier function and enhance the production of ceramides by keratinocytes (Lew et al., 2012) reduce the appearance of wrinkles, tightens pores and contains exfoliating properties, remodelling of epidermal and dermal cells and improves dry and dull skin, reduces skin microflora, activation of TLR, modulate angiotensin vascular endothelial growth factor and cytokines secretion reducing erythema (Muizzuddin et al., 2012) pLTA, which has anti-photoaging effects on human skin by regulating matrix meralloprotionase-1 (MMP1) expression. (Jeong et al., 2016) reported that Lactobacillus prevented skin inflammation and reduced biomarkers of inflammation in mice suffering from psoriasis(Schauber et al., 2008).

These results suggest a symbiotic relationship that leaves the host more prepared to combat pathogenic infection. Furthermore, the release of the AMPs LL-37 \& HBD2,3 is amplified by these microbes conferring dual attack on pathogens as is depicted by the positive correlation between concentration of AMPs and microbial load.

The clinical assessment of skin tolerance by the dermatologist revealed that exposed areas such as hand back has better dermal health compared to antecubital fossa, may be due to higher level of LL-37 as the sunlight induces the synthesis of vitamin D this increased level of LL-37 activates pro and anti-inflammatory 
mediators.

Moreover the greater microbial diversity of exposed skin sites is due to its higher interaction with external environment promoting better skin tolerance. Furthermore, exposure could also modulate resident microflora by encouraging evaporation of water, reducing the accumulation of secretions and maintaining the skin $\mathrm{pH}$.

These factors may contribute to better dermal health in exposed compared with unexposed sites. When the bacterial ecosystem is balanced and differentiated, the skin remains healthy.

Clinical research has shown that blemishprone skin has a less-diverse skin microbiome, over-populated with pathogens and damaging stressors-compared to those with healthy skin (Prescot et al., 2017).

Little is known about many of the other bacterial species on skin due to their low abundance and apparent harmlessness.

In the present era skin diseases are on the verge of increasing day by day, the last decade has seen drastic increase in antibiotic resistance paving a challenge to combat skin infections. In addition to causing diseases some of the microbes potentially also play an opposite role by protecting the host.

The reticuloauricular crease has maximum TVC, biomarkers, epidermal hydration and better dermal health depicting a positive correlation between all these parameters. The present findings suggests that microenvironment i.e. biophysical characters influence type of microflora which in turn affects the level of biomarkers and health status of skin by preventing the growth of pathogenic organisms.
The complex host-microbe and microbemicrobe interactions on the surface of human skin pave a way to use these symbiotic microbes by selective modulation of microflora (pre- and/or skin probiotics) as novel therapeutic approach to dermatological diseases.

\section{Future prospects}

Further work should be done by studying large samples to standardize the CFU of commensal bacteria to be used in skin ointments for therapeutic purpose.

\section{Acknowledgement}

SS is thankful for encouragement and support by Dr. D.K. Sharma, Dean, Department of CSE MIET, Meerut, India.

\section{References}

Bierbaum G, Gotz F, Peschel A. The biosynthesis of the lantibiotics epidermin, gallidermin, Pep5 and epilancin K7. Antonie Van Leeuwenhoek.1996; 69:119-127.

Chiller K, Selkin BA, Murakawa GJ. Skin Microflora and Bacterial Infections of the Skin. Journal of Investigative Dermatology. 2001; 6:3:170-174.

Cogen AL, Nizet V, Gallo RL. Staphylococcus epidermidis functions as a component of the skin innate immune system by inhibiting the pathogen Group A Streptococcus. J Invest Dermatol.2007; 127:S131

Cogen AL, Nizet V, Gallo RL.Skin microbiota: a source of disease or defence? Br J Dermatol. Mar 2008; 158(3):442-55.

Cogen AL, Yamasaki K, Sanchez KM, Dorschner RA, Lai Y, MacLeod DT, Torpey JW, Otto M, Nizet V, Kim JE, Gallo RL. Selective Antimicrobial Action Is Provided by PhenolSoluble Modulins Derived from Staphylococcus epidermidis, a Normal Resident of the Skin.J Invest Dermatol.2010;130:192-200

Crack LR, Jones L, GN Malavige, Patel V, Ogg GS. Human antimicrobial peptides LL-37 and human $\beta$-defensin- 2 reduce viral 
replication in keratinocytes infected with varicella zoster virus. Clin Exp Dermatol.2012; 37(5): 534-43.

Dekio I, Hayashi H, Sakamoto M, Kitahara M, Nishikawa T, Suematsu M, Benno Y (2005) Detection of potentially novel bacterial components of the human skin microbiota using culture-independent molecular profiling. J Med Microbiol.Dec. ;54(Pt 12):1231-8.

Domingo P, Fontanet A. Management of complications associated with totally implantable ports in patients with AIDS. AIDS Patient Care STDS.2001; 15:7-13.

Grice EA Segre JA.The skin microbiome. Nat Rev Microbiol.2011 ;9:244-53. Grice EA, Kong HH,Renaud $\mathrm{G}$ et al.,. A diversity profile of the human skin microbiota. Genome Res. 2008; 18:1043-50.

Hans $M$ and Hans VM. Epithelial Antimicrobial Peptides: Guardian of the Oral Cavity. International Journal of Peptides.2014; Article ID 370297.

Harvey N. Mayrovitz, Jennifer Wong and Madeline Fasen, Age and Hydration dependence of jowl and forearm skin firmness in young and mature women, Journal of Cosmetic Dermatology, 2017:17 (6):1262-1270.

Hoyle BD, Costerton JW. Bacterial resistance to antibiotics: the role of biofilms. Prog Drug Res. 1991; 37:91-105.

Ian A. Myles, Jensen D. Reckhow, Kelli W. Williams, Inka Sastalla, Karen M. Frank, Sandip K. Datta A method for culturing Gramnegative skin microbiota. BMC Microbiol. 2016; 16: 60.

Jeong JH, Lee CY, Chung DK. Probiotic Lactic Acid Bacteria and Skin Health. Crit Rev Food Sci Nutr. 2016; 56 (14): 2331-7.

Julie N O'Sullivan, Mary C Rea, Paula M O'Connor, Colin Hill, R Paul Ross, Human skin microbiota is a rich source of bacteriocinproducing staphylococci that kill human pathogens, FEMS Microbiology Ecology.2019; 95(2): 241.

Lai Y, Anna Di Nardo, Nakatsuji T, Leichtle A, Yang Y, Cogen A L., Wu ZR, Hooper L V., Sonja V A, Katherine A. R, Huang CM,Ryan AF, Gallo LR.Commensal bacteria regulate TLR3-dependent inflammation following skin injuryNat Med. 2009; 15(12): 1377-1382.

Lai Y, Cogen AL, Radek KA, Park HJ, Macleod DT, Leichtle A, Ryan AF, Di Nardo A, Gallo RL.Commensal bacteria regulate TLR3dependent inflammation following skin injury. J Invest Dermatol.2010; 130:22112221.

Lew, L.C. and Liong, M.T. Divalent ions of Mn and $\mathrm{Mg}$ improved sphingomyelinase activity of Lactobacillus rhamnosus FTDC 8313.Biosci Biotechnol Biochem in press. 2012

Li D, Lei H, Li Z, Li H, Wang Y, Lai Y. A Novel Lipopeptide from Skin Commensal Activates TLR2/CD36-p38 MAPK Signaling to Increase Antibacterial Defense against Bacterial Infection.Plos one.2013; 8(3):e58288.

Maja-Lisa Clausen, H.-C. Slotved, Karen A. Krogfelt, Tove Agner Measurements of AMPs in stratum corneum of atopic dermatitis and healthy skin-tape stripping technique Sci Rep. 2018; 8: 1666.

Megyeri K, Orosz L, Bolla S. Propionibacterium acnes Induces Autophagy in Keratinocytes: Involvement of Multiple Mechanisms. J Invest Dermatol.2018; 138(4):750-9

Moon SH, Roh HS, Kim YH.Antibiotic resistance of microbial strains isolated from Korean acne patients. J Dermatol.2012; 39(10):8337.

Muizzuddin N, Maher W, Sullivan M, Schnittger $\mathrm{S}$, Mammone T. Physiological effect of a probiotic on skin. J Cosmet Sci.2012 ;63(6):385-95.

Naik S, Bouladoux N, Wilhelm C, Molloy MJ, Salcedo R, Kastenmuller W, Deming C, Quinones M, Koo L, Conlan S. Compartmentalized Control of Skin Immunity by Resident Commensals. Science.2012; 337:1115-1119.

Nakamura Y, Oscherwitz J, Cease KB, Chan SM, Muñoz-Planillo R, Hasegawa M, Villaruz AE, Cheung GY, McGavin MJ, Travers JB. Staphylococcus $\delta$-toxin promotes mouse allergic skin disease by inducing mast cell degranulation. Nature. 2013; 503: 397-401.

Nakatsuji T, Chen TH, Saisindhu N. Antimicrobials from human skin commensal bacteria protect against Staphylococcus 
aureus and are deficient in atopic dermatitis Science Translational Medicine. 2017; 9 (378): 4680.

Nakatsuji T, Chiang HI, Jiang SB, Nagarajan H, Zengler K, Gallo RL. The microbiome extends to subepidermal compartments of normal skin. Nat Commun.2013; 4:1431.

Nelson A, Hultenby K, Hell E, Riedel HM, Brismar H, Flock JI, Lundahl J, Giske CG, Marchini G. Staphylococcus epidermidis isolated from newborn infants express piluslike structures and are inhibited by the cathelicidin-derived antimicrobial peptide LL37. Pediatr Res. 2009; 66(2):174-8.

Nipa KK. Human Skin Bacteria: Innocuous Symbiotic Association, Pathogenic Action and Antibiotic Effect.Plant Environment Development. 2015; 4 (1):06-13.

Olutiola, PO, Famurewa O and Sonntag, HG. Introduction to General Microbiology: A Practical Approach. 2nd Edn., Bolabay Publications, Ikeja, Nigeria.2000

Otto M, Echner H, Voelter W. Pheromone crossinhibition between Staphylococcus aureus and Staphylococcus epidermidis. Infect Immun.2001; 69:1957-1960.

Otto M. Staphylococcus aureus and Staphylococcus epidermidis peptide pheromones produced by the accessory gene regulator agr system. Peptides. 2001; 22:1603-1608.

Overturf GD, Sherman MP, Scheifele DW, et al.,.Neonatal necrotizing enterocolitis associated with delta toxin-producing methicillin-resistant Staphylococcus aureus. Pediatr Infect Dis J.1990; 9:88-91.

Platsidaki E, Dessinioti C. Recent advances in understanding Propionibacterium acnes (Cutibacterium acnes) in acne. 2018; F1000 Res.; 7.

Prescot SL, Larcombe DL, Logan AC, West C, Burks W, Caraballo L, Levin M, Etten EV, Horwitz P, Kozyrskyi A, Campbell DE. The skin microbiome: impact of modern environments on skin ecology, barrier integrity, and systemic immune programming.World Allergy Organization Journal.2017;10:29.

Saporito P, Vang Mouritzen M, Løbner-Olesen A, Jenssen H. LL-37 fragments have antimicrobial activity against Staphylococcus epidermidis biofilms and wound healing potential in HaCaT cell line. J Pept Sci. 20181;24(7)

Schauber, J. and Gallo, R.L. Antimicrobial peptides and the skin immune defense system. J Allergy Clin Immunol. 2008; 122, 261-266.

Tacconelli E, Tumbarello M, Pittiruti M. Central venous catheter-related sepsis in a cohort of 366 hospitalised patients. Eur J Clin Microbiol Infect Dis.2001; 16:203-209.

Teruaki N, Tiffany H, Anna M. B, Lynnie L. T, Sang-JN, Karina T., Shirakawa KT, Wei Zhou W, Oh J, Otto M, Fenical W and Gallo RL. A commensal strain of Staphylococcus epidermidis protects against skin neoplasia.Science Advances. 2018. 4(2):eaao4502.

Treat J, William D. J, Nachamkin I et al.,. Growth Inhibition of Trichophyton Species by Pseudomonas aeruginosa. Arch Dermatol. 2007;143(1):61-64.

Wanke I, Steffen H, Christ C, Krismer B, Götz F, Peschel A, Schaller M, Schittek B.(2011) Skin commensals amplify the innate immune response to pathogens by activation of distinct signaling pathways. J Invest Dermatol. 2011;131(2):382-90.

$\mathrm{Xu} \mathrm{L}$, Feng Wang, Yin Shen, Hongyan Hou, Weiyong Liu, Cailin Liu, Cui Jian, Yue Wang, Mingyue Sun, Ziyong Sun. Pseudomonas aeruginosa inhibits the growth of pathogenic fungi: In vitro and in vivo studies.Exp Ther Med. 2014;7(6): 15161520.

$\mathrm{Xu}$ LQ, Zeng JW, Jiang CH, Wang $\mathrm{H}$, Li YZ, Wen WH, Li JH, Wang F, Ting WJ, Sun ZY, Huang CY. Isolation and determination of four potential antimicrobial components from Pseudomonas aeruginosa extracts. Int J Med Sci. 2017; 14(13):1368-1374.

Zheng Z, Zhang LM, Xi W L, Xiao J L, Jun J, Lin C, Jian Z Z. Expressions of Antimicrobial Peptides LL-37, Human Beta Defensin-2 and -3 in the Lesions of Cutaneous Tuberculosis and Tuberculids.Chin Med J (Engl). 2016; 129(6): 696-701. 


\section{How to cite this article:}

Sonia Sharma, Alka Sagar, Saurabh Singh Yadav, Pramod W. Ramteke. 2020. Correlation of Biomarker and Biophysical Parameters with Microflora at Different Skin Sites in Young Women (20-21yrs.) of Meerut. Int.J.Curr.Microbiol.App.Sci. 9(02): 1076-1088. doi: https://doi.org/10.20546/ijcmas.2020.902.126 